\title{
THE CHANGING PARADIGMS OF EMPLOYEE RELATIONS - AN EMPIRICAL STUDY OF DRIVERS AND CONDUCTORS IN A.P.S.R.T.C (ANDHRA PRADESH STATE ROAD TRANSPORT CORPORATION)
}

\section{A. R. VIJAYA CHANDRAN}

Associate Professor, Institute of Management Christ University, Hosur, Bangalore, India

Unions have enjoyed a close relationship with the state and political class which enjoyed complete freedom in Independent India. But this has developed a status where unions could not develop strong roots in their respective constituents and for namesake their existence continued. The huge number of workforce outside the organized sector is posing a big challenge in Indian industrial relations as unorganized sector. In APSRTC organization also as the researcher observed in some depots the contractual employees were coming up to $27 \%$ to $35 \%$ to the total number of drivers and conductors. As the transportation sector is gaining more importance in the same manner the issues in the sector is gaining is more important. In this research study, though the limited material was available still the researcher was able to find out enough material and an elaborate research was made.

Data analysis was done by administering modern tools and techniques like Anova, Chi square and Regression analysis by utilizing SPSS package 20.0 version. The researcher was able to find out that there will be a significant impact on the industrial relations if employee satisfaction is taken care of in a proper way. Also, it was deduced that it leads to customer satisfaction. From the above study we can also draw a conclusion that company's competitiveness and profitability will be affected by production oriented practices.
\end{abstract}

KEYWORDS: Employee relations, Unions \& Management

Received: Dec 15, 2018; Accepted: Jan 05, 2019; Published: Jan 24, 2019; Paper Id.: IJHRMRFEB201915

\section{INTRODUCTION}

As the inflow of FDI is increasing and MNC's are in the process of setting up their manufacturing bases in India employment opportunities has been going on increasing in our country. As the employment opportunities are going on increasing, employment relations are acquiring lots of importance in day to day life. There are visible concerns inthe manufacturing sector, and more so in automotive industries throughout India. The service sector had no major fall out in terms of Industrial relations issues barring a few instances in public sector banks and insurance companies. Mathematical solution might not be written for man-management problems which is plaguing the industry. But experience shows that enlightened knowledge and expertise can be a beacon for implementing strategies and processes that would produce reasonably good results even in turbulent times. By the ongoing happenings in India as an IR professional we can assume that India is transitioning into a capitalistic economy. Even till today there is a strong lobby in our system which supports archaic labour laws. Even though L.P.G (liberalization, privatization and globalization) is happening still government is the biggest employer in our country. This study focusses on one of the state government establishment which employs more than one lakh 
people. The success of the new liberalised policies depends on the performance of all three players (of industrial relations) in our country that is Employers, Employees and Government. If the twin objectives national development and increased social justice have to be achieved then there must be harmonious relations between management and unions. Labour and management do not operate in isolation. They are parts of larger system. Employee relations also include technology at the workplace, socio-political environment, nations labour policy and attitude of the trade unions its leaders towards its management vice-versa.

\section{IMPORTANCE OF THE STUDY}

All the above statements indicate and highlight the importance of cordial relations between employee and management relations and its contribution towards the production of that organization. Though much employee relations development is cherished and achieved various complex problems do arise in the field of labour as a result of industrialization, such as unfavourable work environment, unhealthy working and living conditions, lack of basic amenities for toiling masses and the resultant low standard of living, constant dissatisfaction within and bickering about low wages, insecurity of jobs and personal problems. Thus, if not given attention in time, might lead to the problems such as high attrition rate, high absenteeism, low turnout and above all accidents which leads to dissatisfaction among labourers and ultimately it leads to bad organisational relations and which gets reflected upon customer satisfaction. Andhra Pradesh State Road Transport Corporation (APSRTC) is a service oriented organization and it might be difficult to survive without passengers (customers). It has to stress more upon good employee relations to satisfy its customers (passengers). This article is a humble attempt tostudy the gaps between Management and Unions in providing better satisfaction to drivers and conductors.

\section{METHODOLOGY}

Out of 28 depots 5 depots were randomly selected for collection of data. Bus Depots were selected in the Greater Hyderabad Municipal Corporation region (GHMC). In this study random sampling was done as well as statistical tools such as ANOVA, Regression Analysis, Chi Square, Reliability test were administered.

A huge amount of literature which was relevant for the present article has been collected. Author was able to study Drivers and Conductors their working conditions and their job satisfaction. Though the responses were received from different cadres of employee's majority were from drivers and conductors. A vast number of web sites and journals were studied and the huge amount of literature survey was gathered by the researcher. A questionnaire of 56 was administered to respondents and those responses were analysed. Recent statistical tools were utilised to decipher the data which was collected. The SPSS package 20.0 version was utilised to interpret the data which was collected. Interviews were conducted by administering questionnaires to 1000 (One Thousand in which 970 were males and 30 were females) Employees of the corporation from 5 depots which were randomly selected. Age, Marital status, Qualification, Service and Designation were the demographic variables which were considered for this study.

\section{LIMITATIONS}

There were limitations while collecting data from different employees. Mostly all the female employees who were working as conductors were reluctant to share the information as they feared reprisal from union leaders as well as from the management. And male employees were apprehensive that they might be posted to another area which might affect their work life balance. By taking the above circumstantial problems into consideration APSRTC has to undergo 
Pradesh State Road Transport Corporation)

competition in the open market and acquire its resources. It was clearly quoted by Paul S. Goodman, Mark Fichman, F. Javier Lerch Panda R. Snyden (1995) ${ }^{1}$, quoted that "to acquire resources, organizations must inevitably interact with their social environments. No Organization is completely self-contained - survival comes when the organization adjusts to, and copes with its environment, not only when it makes efficient internal adjustments".

\section{OBJECTIVES}

- Impact of work pressure and training on drivers and conductors satisfaction.

- Contract drivers and conductors are performing their duties for enhancement of customer satisfaction.

- To measure protection of drivers and conductors while performing duties and its impact on customer satisfaction.

\section{HYPOTHESES}

$\mathbf{H}_{\mathbf{0}}$ 1: There is no significant association between experience, age, marital status, and gender and work pressure.

$\mathbf{H}_{0}$ 2: There is no significant association between age, marital status and length of service and training given to drivers and conductors to enhance customer satisfaction.

$\mathbf{H}_{\mathbf{0}}$ 3: There is no significant association between protection to drivers and conductors on duty and gender.

$\mathbf{H}_{\mathbf{0}}$ 4: There is no significant association between employees and passengers committees formed at depot levels and increase in confidence amongst passengers.

H05: There is no significant association between qualification, service, age and marital status and union involvement in redressal of passenger complaints for customer's satisfaction.

\section{DATA ANALYSIS AND INTERPRETATION} ANALYSIS OF HYPOTHESES

$\mathbf{H}_{\mathbf{0}} \mathbf{1}$ There is no significant association between experience, age, marital status, and gender and work pressure.

Table 1

\begin{tabular}{|c|c|c|c|c|c|c|c|c|}
\hline \multirow{2}{*}{\begin{tabular}{c} 
Filling up $\begin{array}{c}\text { So } \\
\text { of } \\
\text { Vacancies }\end{array}$ \\
\cline { 2 - 9 }
\end{tabular}} & $\begin{array}{c}\text { Chi } \\
\text { Square }\end{array}$ & $\begin{array}{c}\text { Strength of } \\
\text { Association }\end{array}$ & $\begin{array}{c}\text { Chi } \\
\text { Square }\end{array}$ & $\begin{array}{c}\text { Strength of } \\
\text { Association }\end{array}$ & $\begin{array}{c}\text { Chi } \\
\text { Square }\end{array}$ & $\begin{array}{c}\text { Strength of } \\
\text { Association }\end{array}$ & $\begin{array}{c}\text { Chi } \\
\text { Square }\end{array}$ & $\begin{array}{c}\text { Strength of } \\
\text { Association }\end{array}$ \\
\cline { 2 - 9 } & 0.000 & 0.135 & 0.000 & 0.122 & 0.079 & 0.091 & 0.162 & 0.081 \\
\hline
\end{tabular}

$\mathbf{H}_{\mathbf{0}} \mathbf{2}$ There is no significant association between age, marital status and length of service and training given to drivers and conductors to enhance customer satisfaction.

Table 2

\begin{tabular}{|c|c|c|c|c|c|c|}
\hline \multirow{2}{*}{$\begin{array}{c}\text { Training } \\
\text { given to }\end{array}$} & \multicolumn{2}{|c|}{ Age } & \multicolumn{2}{c|}{ Marital Status } & \multicolumn{2}{c|}{ Service } \\
\cline { 2 - 7 } $\begin{array}{c}\text { Drivers } \\
\text { and }\end{array}$ & $\begin{array}{c}\text { Chi } \\
\text { Square }\end{array}$ & $\begin{array}{c}\text { Strength of } \\
\text { Association }\end{array}$ & $\begin{array}{c}\text { Chi } \\
\text { Square }\end{array}$ & $\begin{array}{c}\text { Strength of } \\
\text { Association }\end{array}$ & $\begin{array}{c}\text { Chi } \\
\text { Square }\end{array}$ & $\begin{array}{c}\text { Strength of } \\
\text { Association }\end{array}$ \\
\cline { 2 - 7 } Conductors & 0.000 & 0.148 & 0.092 & 0.089 & 0.000 & 0.153 \\
\hline
\end{tabular}

$\mathbf{H}_{\mathbf{0}} \mathbf{3}$ There is no significant association between protection to drivers and conductors on duty and gender. 
Table 3

\begin{tabular}{|c|c|c|c|c|c|c|c|c|}
\hline Protection to & \multicolumn{2}{|c|}{ Marital Status } & \multicolumn{2}{|c|}{ Age } & \multicolumn{2}{c|}{ Qualification } & \multicolumn{2}{c|}{ Service } \\
\cline { 2 - 9 } $\begin{array}{c}\text { Drivers and } \\
\text { Conductors } \\
\text { on duty }\end{array}$ & $\begin{array}{c}\text { Chi } \\
\text { Square }\end{array}$ & $\begin{array}{c}\text { Strength of } \\
\text { Association }\end{array}$ & $\begin{array}{c}\text { Chi } \\
\text { Square }\end{array}$ & $\begin{array}{c}\text { Strength of } \\
\text { Association }\end{array}$ & $\begin{array}{c}\text { Chi } \\
\text { Square }\end{array}$ & $\begin{array}{c}\text { Strength of } \\
\text { Association }\end{array}$ & $\begin{array}{c}\text { Chi } \\
\text { Square }\end{array}$ & $\begin{array}{c}\text { Strength of } \\
\text { Association }\end{array}$ \\
\cline { 2 - 10 } & 0.205 & 0.077 & 0.000 & 0.124 & 0.000 & 0.151 & 0.000 & 0.180 \\
\hline
\end{tabular}

$\mathbf{H}_{\mathbf{0}} 4$ There is no significant association between employees and passengers committees formed at depot levels and increase in confidence amongst passengers.

Table 4

\begin{tabular}{|c|c|c|c|c|c|c|}
\hline Committees of & \multicolumn{2}{|c|}{ Qualification } & \multicolumn{2}{|c|}{ Age } & \multicolumn{2}{c|}{ Service } \\
\cline { 2 - 7 } $\begin{array}{c}\text { Drivers and } \\
\text { Conductors and } \\
\text { Passengers at } \\
\text { Depot Levels }\end{array}$ & $\begin{array}{c}\text { Chi } \\
\text { Square }\end{array}$ & $\begin{array}{c}\text { Strength of } \\
\text { Association }\end{array}$ & $\begin{array}{c}\text { Chi } \\
\text { Square }\end{array}$ & $\begin{array}{c}\text { Strength of } \\
\text { Association }\end{array}$ & $\begin{array}{c}\text { Chi } \\
\text { Square }\end{array}$ & $\begin{array}{c}\text { Strength of } \\
\text { Association }\end{array}$ \\
\cline { 2 - 7 } & 0.000 & 0.173 & 0.000 & 0.198 & 0.000 & 0.203 \\
\hline
\end{tabular}

$\mathbf{H}_{0} \mathbf{5}$ There is no significant association between qualification, service, age and marital status and union involvement in redressal of passenger complaints for customer's satisfaction.

Table 5

\begin{tabular}{|c|c|c|c|c|c|c|c|c|}
\hline \multirow{2}{*}{$\begin{array}{c}\text { Union } \\
\text { Involvement in } \\
\text { Solving Passenger } \\
\text { Complaints }\end{array}$} & \multicolumn{2}{|c|}{ Qualification } & \multicolumn{2}{c|}{ Service } & \multicolumn{2}{c|}{ Age } & \multicolumn{2}{c|}{ Marital Status } \\
\cline { 2 - 9 } & $\begin{array}{c}\text { Chi } \\
\text { Square }\end{array}$ & $\begin{array}{c}\text { Strength of } \\
\text { Association }\end{array}$ & $\begin{array}{c}\text { Chi } \\
\text { Square }\end{array}$ & $\begin{array}{c}\text { Strength of } \\
\text { Association }\end{array}$ & $\begin{array}{c}\text { Chi } \\
\text { Square }\end{array}$ & $\begin{array}{c}\text { Strength of } \\
\text { Association }\end{array}$ & $\begin{array}{c}\text { Chi } \\
\text { Square }\end{array}$ & $\begin{array}{c}\text { Strength of } \\
\text { Association }\end{array}$ \\
\cline { 2 - 9 } \\
\hline
\end{tabular}

Reliability test was administered and it was found that the value was more than 0.7 indicating that all the analysis was reliable in nature.

Cronbach's alpha has been administered to check the reliability of the questionnaire.

Table 6

\begin{tabular}{|c|c|}
\hline \multicolumn{2}{|c|}{ Reliability Statistics } \\
\hline Cronbach's Alpha & N of Items \\
\hline .744 & 33 \\
\hline
\end{tabular}

Before proceeding for factor analysis the eligibility of the data was done by checking KMO- Bartlett's test which is a measure of sampling adequacy.

KMO AND BARTLETT'S TEST

Table 7

\begin{tabular}{|c|c|c|}
\hline \multicolumn{2}{|c|}{$\begin{array}{r}\text { Kaiser-Meyer-Olkin Measure of } \\
\text { Sampling Adequacy. }\end{array}$} & .809 \\
\hline \multirow{2}{*}{$\begin{array}{c}\text { Bartlett's Test } \\
\text { of Sphericity }\end{array}$} & Approx. Chi-Square & 30168.577 \\
\cline { 2 - 3 } & Df & 528 \\
\cline { 2 - 3 } & Sig. & .000 \\
\hline
\end{tabular}

The KMO value is 0.809 which is greater than $0.5(0.809>0.5)$ indicating multivariate normality among variables. Further, significance value is less than 0.005 giving an indication that factor analysis can be continued. 
Table 8

\begin{tabular}{|c|c|c|c|c|}
\hline \multicolumn{5}{|c|}{ Correlations } \\
\hline & & $\begin{array}{c}\text { Employee } \\
\text { Satisfaction }\end{array}$ & $\begin{array}{c}\text { Union } \\
\text { Management }\end{array}$ & $\begin{array}{c}\text { Customer } \\
\text { Satisfaction }\end{array}$ \\
\hline \multirow{3}{*}{$\begin{array}{l}\text { Employee } \\
\text { Satisfaction }\end{array}$} & Pearson Correlation & 1 & $.592^{* * 3}$ & $.602^{* * *}$ \\
\hline & Sig. (2-tailed) & & .000 & .000 \\
\hline & $\mathrm{N}$ & 994 & 993 & 989 \\
\hline \multirow{3}{*}{$\begin{array}{l}\text { Union } \\
\text { Management }\end{array}$} & Pearson Correlation & $.592^{* * *}$ & 1 & $.505^{* * *}$ \\
\hline & Sig. (2-tailed) & .000 & & .000 \\
\hline & $\mathrm{N}$ & 993 & 998 & 992 \\
\hline \multirow{3}{*}{$\begin{array}{l}\text { Customer } \\
\text { Satisfaction }\end{array}$} & Pearson Correlation & $.602^{* * *}$ & $.505^{* * *}$ & 1 \\
\hline & Sig. (2-tailed) & .000 & .000 & \\
\hline & $\mathrm{N}$ & 989 & 992 & 994 \\
\hline
\end{tabular}

**. Correlation is significant at the 0.01 level (2-tailed).

From the above correlation matrix Employee Satisfaction is positively correlated with Employee Management relations and Customer Satisfaction. Further, it is highly correlated with Customer Satisfaction. It is showing that employee satisfaction, passenger satisfaction and union management relations are all related to each other. Robin L. Snipes et al $(2005)^{2}$ felt that Employees who feel satisfied with their jobs provide higher levels of customer satisfaction.

For good and trustworthy relations between union and management attitudes should also change. Unites States General Accounting Office (1994) ${ }^{3}$ maintained that the "us versus them" attitude and behaviour of both management and Unions must end if the Postal service is to be successful in a competitive environment. It shows the importance of cordial relations which should exist between union and management.

\section{REGRESSION ANALYSIS}

Table 9

\begin{tabular}{|c|c|c|c|c|}
\hline \multicolumn{5}{|c|}{ Model Summary } \\
\hline Model & R & R Square & Adjusted R Square & Std. Error of the Estimate \\
\hline 1 & $.628^{\text {a }}$ & .395 & .394 & .419 \\
\hline \multicolumn{5}{|c}{} \\
\hline
\end{tabular}

a. Predictors: (Constant), Union Management, Employee Satisfaction

R: Represents the multiple correlation coefficients with a range lies between -1 and +1 . Since the R's value is 0.628 it means Customer Satisfaction has a positive relationship with Union Management and Employee Satisfaction.

R square: Represents the coefficient of determination and ranges between 0 and 1 . Since the $\mathrm{R}$ square value is 0.395, $39 \%$ of the variation in Customer Satisfaction is explained by Union Management and Employee Satisfaction.

Table 10: ANOVA ${ }^{\mathrm{a}}$

\begin{tabular}{|c|l|c|c|c|c|c|}
\hline \multicolumn{2}{|l|}{ Model } & Sum of Squares & Df & Mean Square & F & Sig. \\
\hline \multirow{3}{*}{1} & Regression & 112.955 & 2 & 56.478 & 321.392 & $.000^{b}$ \\
\cline { 2 - 7 } & Residual & 173.092 & 985 & .176 & & \\
\cline { 2 - 7 } & Total & 286.047 & 987 & & & \\
\hline
\end{tabular}

From the above ANOVA table F value is significant (significant value is less than 0.05) it means the dependent variable placement percentage is more reliable. 
Table 11: Coefficients Table

\begin{tabular}{|c|c|c|c|c|c|c|}
\hline \multicolumn{7}{|c|}{ Coefficients } \\
\hline \multirow{2}{*}{\multicolumn{2}{|c|}{ Model }} & \multicolumn{2}{|c|}{$\begin{array}{c}\text { Unstandardized } \\
\text { Coefficients } \\
\end{array}$} & \multirow{2}{*}{$\begin{array}{c}\begin{array}{c}\text { Standardized } \\
\text { Coefficients }\end{array} \\
\text { Beta } \\
\end{array}$} & \multirow{2}{*}{$\mathbf{t}$} & \multirow{2}{*}{ Sig. } \\
\hline & & B & Std. Error & & & \\
\hline \multirow{3}{*}{1} & (Constant) & 1.079 & .069 & & 15.638 & .000 \\
\hline & Employee Satisfaction & .591 & .039 & .466 & 15.140 & .000 \\
\hline & Union Management & .240 & .032 & .228 & 7.396 & .000 \\
\hline
\end{tabular}

The model coefficient table reports the coefficients for Employee Satisfaction and Union Management along with the significant value. The model coefficients are used in the construction of Regression equation. A low significant value of less than 0.05 for Employee Satisfaction and Union Management indicates they strongly impact the Customer Satisfaction.

The regression equation for the above data has been given below.

Customer Satisfaction $=1.079+0.591($ Employee Satisfaction $)+0.240$ (Union management $)$.

The above equation is the calculated contribution for the tested elements to achieve Customer Satisfaction effectively. From the Regression equation, we notice that all the independent variables have a positive impact on Customer Satisfaction. Stephen J Dury and Roderick D. Iverson $(2005)^{4}$ quoted that perceptions of a cooperative labour relations climate were positively influenced by procedural justice, Unions willingness to adopt an integrative approach to bargaining management's willingness to share information freely with the Union. In this successful partnership they were able to find out that US Corporation and the two unions have gone beyond their traditional role of negotiating wages and working conditions in adversarial collective bargaining. Through this dialogue with the company and unions have reached a series of mutual decisions that have protected union members' jobs and reorganized their work in a way that increases worker and customer satisfaction and that benefits the firm

\section{CONCLUSIONS}

In the era of challenges where government is proposing for make in India the challenges for sustainable industrial relations might be:

Involvement of line managers in day to day functioning, Emotional connect with the employees, appreciation of business eco-system in which the company is functioning, Case by case solution has to be found out last not but the least transparency has to be made in all activities of an organization.

Carrie G. Donald, Thomas G. Lyons et.al $(2001)^{5}$ maintained that "the basis of cooperation between labour and management is recognition of mutual interests". They stressed upon the labour management cooperation by stating that partnership takes cooperation a step further by reassigning decision making power. In a time when public sector agencies and companies are increasingly in competition with the private sector, workplaces where employees are active participants in guiding the organization will be essential to achieving and maintaining quality and service oriented outlook. 
1. Paul S. Goodman, Mark Fichman, F. Javier Lerch Panda R. Snyden, Carnegie Mellon University, "Customer - Firm relationships, involvement and customer satisfaction", Academy of Management Journal 1995, Vol. 38, No. 5, 1310-1324.

2. Lai, S. (2016). Social Integration and Job Satisfaction of Employees With Disability: Comparing and Contrasting With General Newcomers.

3. Robin L. Snipes, Sharon L. Oswald, Michael Latous Achilles, A. Armenakis, "The effect of job satisfaction facets on customer perceptions of service quality an employee level analysis” - Journal of Business Research, Volume 58, Issue 10, October 2005, Pages $1330-1339$.

4. United States General Accounting Office Report to Congressional Requestors in their title "US Postal Service Labor Management problems persist on the work room floor" September 1994 GAO/GGD - 94 201A Volume I postal service Labour Management Relations PP No. 4

5. PP, S. (2017). Job Satisfaction of Women Teachers With Special Reference to Malappuram District.

6. Stephen J Dury and Roderick D. Iverson, “Labour - Management cooperation: Antecedents and impact on organizational performance” in Industrial and Labour relations review, Vol. 58 No., July 2005 by Cornell University.

7. Carrie G. Donald, Thomas G. Lyons and Rebecca C. Tribbey in "A partnership for strategic planning and management in public organization” Sage Publications 2001 Volume 25, No. 2 December 2001 176.193.176. 
